\title{
GLOBAL COLLATERAL AND CAPITAL FLOWS
}

\author{
Ana Fostel \\ John Geanakoplos \\ Gregory Phelan \\ Working Paper 25583 \\ http://www.nber.org/papers/w25583 \\ NATIONAL BUREAU OF ECONOMIC RESEARCH \\ 1050 Massachusetts Avenue \\ Cambridge, MA 02138 \\ February 2019
}

We are grateful for feedback from Valentina Bruno, Emmanuel Farhi, Matteo Maggiori, Frank Warnock, and participants at the 2015 NBER IFM Summer Institute. The views expressed herein are those of the authors and do not necessarily reflect the views of the National Bureau of Economic Research.

At least one co-author has disclosed a financial relationship of potential relevance for this research. Further information is available online at http://www.nber.org/papers/w25583.ack

NBER working papers are circulated for discussion and comment purposes. They have not been peer-reviewed or been subject to the review by the NBER Board of Directors that accompanies official NBER publications.

(C) 2019 by Ana Fostel, John Geanakoplos, and Gregory Phelan. All rights reserved. Short sections of text, not to exceed two paragraphs, may be quoted without explicit permission provided that full credit, including $\odot$ notice, is given to the source. 
Global Collateral and Capital Flows

Ana Fostel, John Geanakoplos, and Gregory Phelan

NBER Working Paper No. 25583

February 2019

JEL No. D52,D53,E32,E44,F34,F36,G01,G11,G12

\author{
ABSTRACT \\ volatility. \\ Ana Fostel \\ Department of Economics \\ University of Virginia \\ Monroe Hall, Suite 222 \\ Charlottesville, VA 22903 \\ and NBER \\ anafostel@ virginia.edu \\ John Geanakoplos \\ Department of Economics \\ Yale University \\ Box 208281 \\ New Haven, CT 06520-8281 \\ john.geanakoplos@yale.edu \\ Gregory Phelan \\ 24 Hopkins Hall Drive \\ Schapiro Hall, 314 \\ Economics Department \\ Williamstown MA 01267 \\ gp4@williams.edu
}

Cross-border financial flows arise when (otherwise identical) countries differ in their abilities to use assets as collateral to back financial contracts. Financially integrated countries have access to the same set of financial instruments, and yet there is no price convergence of assets with identical payoffs, due to a gap in collateral values. Home (financially advanced) runs a current account deficit. Financial flows amplify asset price volatility in both countries, and gross flows driven by collateral differences collapse following bad news about fundamentals. Our results can explain financial flows among rich, similarly-developed countries, and why these flows increase 


\section{Introduction}

Recent decades have exhibited a proliferation of financial innovation and dramatic increases in gross international financial flows among financially developed countries. Economists have tended to focus on flows between developed and emerging economies, but gross flows among developed economies are substantial. ${ }^{1}$ If these flows were primarily driven by diversification motives, then one would expect capital flows to dampen shocks and decrease volatility. However, there is ample evidence that financial integration increases volatility and amplifies shocks, suggesting that the nature of these flows are at least in part driven by other motives. We show that cross-border differences in the ability to collateralize financial promises are enough to generate international capital flows because international financial trade is a way of sharing scarce collateral. Critically, these flows amplify global volatility in asset prices and collapse during crises.

\section{Motivating evidence}

The following empirical observations motivate our analysis.

Observation 1: There are substantial gross financial flows between rich countries with similar levels of financial development. These gross financial flows (countries simultaneously buying and selling foreign and domestic assets) are an order of magnitude larger than net trade in assets. In some cases these offsetting flows are heavily concentrated in financial assets and in particular in securitized mortgage securities. First, among developed countries there are substantial foreign holdings of government bonds, and for many countries non-residents make up the largest investor base (Andritzky, 2012). Second, there are substantial gross flows between the U.S. and Europe (see Shin, 2012; Bertaut et al., 2012). These flows were most striking pre-crisis, and while they have partially reversed post-crisis (as did all gross flows), the patterns remain. ${ }^{2}$ Finally, as documented by Hale and Obstfeld (2016), there are substantial gross flows within Europe, and these flows are concentrated in just a few countries: Germany, Belgium, and France stand out among the

\footnotetext{
${ }^{1}$ See for example Bruno and Shin (2014), who discuss implications for intermediation costs.

${ }^{2}$ See BIS locational banking statistics.
} 
core countries, and crucially Ireland behaves much like the core countries, intermediating funds to the other peripheral countries as well as to the core. ${ }^{3}$

Observation 2: Financial integration tends to increase co-movement and volatility, particularly in response to financial shocks, and particularly through banking flows and securitized markets. Many empirical papers find that financial integration increases comovement across countries (see Imbs, 2006; Kose, Otrok and Whiteman, 2008; Davis, 2014). Furthermore, financial crises are particularly likely to propagate. Santis and Gerard (1997) find that severe U.S. market declines are contagious internationally, with domestic crashes propagating through (even diversified) international portfolios. Kalemli-Ozcan, Papaioannou and Perri (2013) find that financial crises induce co-movements among financially integrated countries. Loutskina and Strahan (2015) find that the housing boom was exported via financial integration in securitized markets, thus raising the local effect of collateral shocks and increasing volatility. Andritzky (2012) finds that government bond yield volatility increases in the presence of non-resident investors. Additionally, Acharya and Schnabl (2010) find that the geography of financial crises is determined by global banks and securitized markets, not by "global imbalances" and net flows.

\section{Overview of the model and results}

These observations suggest a need for a theory that can explain both: not only capital flows among similarly-developed, rich countries, but also capital flows correlated with higher volatility. In this paper we propose that cross-country differences in the ability to use assets as collateral can account for both observations. We consider a two-country model with incomplete markets and collateralized financial markets. The two countries, Home and Foreign, are identical in every way except for the sophistication with which their financial systems can use collateral. The Home country has an advanced financial system that enables investors to use a risky asset as collateral to issue state-contingent financial promises. In contrast, in the Foreign country investors can use a risky asset (with

\footnotetext{
${ }^{3}$ From 2000-2007 core European banks increased their balance sheets, intermediating funds from the rest of the world, to finance the net current accounts of the periphery countries-Greece, Italy, Ireland, Portugal, and Spain ("GIIPS"). As a result, core banks borrowed from abroad to invest in GIIPS.
} 
identical payoffs as the Home asset) as collateral to issue non-contingent promises only (collateralized debt). The different ability to collateralize financial promises gives rise to different abilities to create risk-free and negative-beta financial securities (only Home can tranche the asset into negative-beta securities). Our model provides precise predictions regarding the direction of capital flows and their effects on volatility during crises.

We first conduct a static analysis to understand how financial innovation drives capital flows. Crucially, after financial integration both Home and Foreign have access to the same set of financial instruments. Flows arise even though there are no interest rate differentials (or differences in precautionary savings), nor hedging or risk-sharing motives to trade assets (agents are risk-neutral and assets have identical payoffs). And yet asset prices do not converge. One would expect the price difference to disappear between two assets with identical payoffs once integration is allowed, but instead we observe that the difference increases. This difference is due to the gap in collateral values: the Home asset is better collateral since it can be tranched into state-contingent promises whereas the Foreign asset can only be used to issue debt. Moreover, Home runs a current account deficit financed by the sale of its more-expensive assets.

We next consider a dynamic setting to study the effects of financial integration on the volatility of asset prices and capital flows. We find that financial integration generally increases price crashes and can lead to collapses in gross and net flows after bad news. Asset prices in Foreign become much more volatile due to fluctuations in the attractiveness of alternative investments (Home assets that can be tranched). Furthermore, Foreign demand for collateral-backed financial promises (negative-beta securities) increases the collateral value of Home assets, amplifying price fluctuations. Hence, asset prices in both countries become more volatile as a result of financial integration. Furthermore, net and gross financial flows collapse following bad news.

\section{Discussion}

Our proposed mechanism, that financial flows arise as a way to share collateral, has several attractive features and important implications. First, trades driven by global demands to 
share collateral lead to gross international flows even among countries that are otherwise identical. We propose that differences in financial innovation between the U.S. and Europe contributed to the expansion of European banks' balance sheets. ${ }^{4}$ In particular, the ability of the U.S. financial system to leverage and tranche U.S. assets (especially mortgages) created securities in demand by European banks. ${ }^{5}$ Our story provides an attractive hypothesis to explain some of the differences between Ireland, Germany, and the rest of Europe. Since the ability of a country to use assets as collateral is the feature that differentiates countries that are otherwise similarly developed. Finally, if collateral-based financial innovations are an important driver of gross flows, then a logical conjecture is that the wave of securitization beginning in the late 1990s could possibly explain the recent divergence between gross and net global flows.

Second, our story has important implications for asset prices, global financial stability, and crisis transmission. Financial integration tends to increase asset prices, export volatility across borders, and lead to collapses in flows. ${ }^{6}$ While Shin (2012) emphasizes how expanded intermediation by European banks depresses credit spreads in the U.S., we document how global banking flows and financial linkages of the type seen between the U.S. and Europe can create serious spillovers, exporting U.S. volatility to European markets and greatly increasing the fragility of the global financial system.

Our mechanism relies on the fact that there are meaningful cross-country differences in the use of collateral. Indeed, there is indirect suggestive evidence that this is the case. Data on the loan terms for U.S. securities used as collateral in domestic funding markets are only beginning to be collected and used in limited samples (see Copeland, Martin and Walker (2014) and Baklanova et al. (2017) for evidence). In the absence of direct evidence to justify our conjecture, one could instead consider proxies for cross-country differences in demand for and supply of collateral. In countries with limited abilities to use assets

\footnotetext{
${ }^{4}$ European banks may also have an advantage at intermediation (one explanation for the pre-crisis expansion), but our results imply that gross flows would arise even if they do not.

${ }^{5}$ Shin argues that the regulatory environment in Europe and the advent of the Euro enabled banks to easily expand their balance sheets. We argue that the question remains: why did European banks expand by intermediating U.S. assets and liabilities as much as they did?

${ }^{6}$ Bekaert and Harvey (2000) provide empirical evidence that financial integration increases domestic asset prices.
} 
as collateral, we would expect to see two patterns. First, domestic investors that employ leverage should be more likely to invest in the limited set of assets that serve as collateral, which typically means government bonds. Second, domestic investors should be more inclined to purchase from abroad financial assets that can serve as collateral. In contrast, countries that have greater abilities to use assets as collateral should disproportionately supply such assets to the rest of the world. Indeed, the following evidence suggests that there may be underlying differences in how countries treat assets as collateral in funding markets.

Several demand proxies suggest countries have differential needs for collateral. First, there is substantial variation in the degree to which financial institutions (leveraged investors) invest in domestic government debt. Specifically, financial institutions in deep financial centers hold much smaller portfolios of government bonds compared to financial institutions in countries with less-deep financial centers (Andritzky, 2012). Second, there is heterogeneous foreign demand for U.S. long-term debt (Treasury bonds, corporate bonds, and asset-backed securities (ABS)). Developed countries, and especially those with deep financial centers, hold large portfolios of U.S. corporate debt, but less developed G20 countries primarily hold Treasuries, and Asian countries hold comparably much higher portfolios of ABS. ${ }^{7}$ Importantly, there is variation even among rich countries. As an example, the portfolio holdings of Japan look much more like the holdings of China than the holdings of the U.K. Compared to the U.K., Japan holds lots of Treasuries and $\mathrm{ABS}^{8}$

These patterns could reflect cross-country differences in the supply of collateral. In countries that produce less collateral, government bonds (typically good collateral) are

\footnotetext{
${ }^{7}$ According to the U.S. Department of the Treasury TIC data, as of June 2016 roughly $50 \%$ of the U.S. long-term portfolio holdings of countries in Europe, Canada, and Australia were in corporate non-ABS, while the portfolios of Africa, Asia, and Latin America were less than $10 \%$ corporate non-ABS. Similarly, Europe, Canada, and Australia hold fewer than $40 \%$ of U.S. long-term securities in Treasuries, whereas the holdings for Africa, Asia, and Latin America were 75-87 percent.

${ }^{8}$ Japan has $74 \%$ in Treasuries, $13 \%$ in Agency ABS, and $12 \%$ in corporate non-ABS. The UK has $31 \%$ in Treasuries and 65\% in corporate non-ABS. China looks more like Japan, with 15\% in Agency ABS and the rest in Treasuries. Finally, South Korea holds 50\% Treasuries, 23\% Agency ABS, 11\% Agency non-ABS, and $16 \%$ corporate non-ABS.
} 
more valuable for leveraged buyers. ${ }^{9}$ Similarly, countries that do not produce collateral have greater demand for U.S. Treasuries and ABS, which can be used as collateral either directly in funding markets (Treasuries) or indirectly in how they are sold as tranches. ${ }^{10}$ 11

Supply proxies also suggest that countries have different ability to produce collateral. First, global flows are increasingly characterized by demand for "safe assets" and "negative-beta assets," many of which are created through financial innovations in securitized markets. Safe assets originate from the U.S., and to a lesser extent from Europe. According to the External Wealth of Nations dataset from Lane and Milesi-Ferretti (2007), in 2011 the U.S. net supply of safe assets accounted for roughly two-thirds of the global net supply of safe assets, and the Eurozone accounted for another fifth. ${ }^{12}$ Furthermore, from 1980-1990, the global net supply of safe assets was between 2 and 3\% of world GDP, and has risen to $14 \%$ in 2011. The U.S. share was 5\% in 2000 and rose to $9 \%$ in 2011. Many have noted that the increase in safe asset supply has been driven primarily by financial innovations in how the U.S. securitizes assets. Securitization also creates negative-beta assets because some safe assets tend to increase in value in bad states of the world. ${ }^{13}$ Accordingly, these flows are suggestive evidence of differential abilities to use

\footnotetext{
${ }^{9}$ As evidence of this argument, Wang (2016) documents substantial heterogeneous portfolio adjustments among U.S. following quantitative easing (QE). After QE, financial institutions held more foreign long-term bonds, while non-financial organizations reduced holdings of foreign long-term bonds. These patterns are exactly what one would expect when the supply of collateral shrinks (as a result of QE), given heterogeneous demand for leverage and variations in the ability of assets to serve as collateral.

${ }^{10}$ Senior-subordinated tranches implicitly provide investors the ability to use the underlying bonds as collateral. See Gong and Phelan (2016b) for more detail.

${ }^{11}$ As additional supporting evidence, Maggiori, Neiman and Schreger (2017) show that foreign mutual funds demonstrate a "home currency bias," holding low levels of corporate bonds denominated in foreign currency-except when the currency is the dollar. In that case, foreign and U.S. investors hold nearly identical bond portfolios. One potential explanation for this currency preference could be that dollar assets are more readily accepted as collateral in funding markets.

${ }^{12}$ The U.S. net supply of safe assets accounted for $9 \%$ of world GDP, and the Eurozone accounted for 3\%: total global net supply was roughly $14 \%$ of world GDP.

${ }^{13}$ For example, long-maturity bonds increase in price in bad states because long-term interest rates decline, even as the face value of the promised payoffs remain the same. Trade in these securities have important consequences for gross flows. Shin (2012) documents how European banks greatly expanded their balance sheets by increasing both U.S. assets and liabilities (European banks borrowed from U.S. markets and purchased U.S. assets). Similarly, Bertaut et al. (2012) show that during the 2000s European investors purchased U.S. asset-backed securities and similar securities. Additionally, Bertaut et al. (2012) provide consistent evidence of differential abilities to supply securitized assets.
} 
assets as collateral.

The rest of the paper is organized as follows. Section 2 reviews the related literature. Section 3 presents the basic general equilibrium model with collateral. Section 4 studies the effects of financial integration in a static model. Section 5 uses a three-period model to study the consequences of financial integration on price and flows volatility. Section 6 concludes. All supplemental material is presented in the Appendix.

\section{Related Literature}

Our paper follows the model of collateral equilibrium developed in Geanakoplos (1997, 2003), Fostel and Geanakoplos (2008, 2012a,b, 2015, 2016), Geanakoplos and Zame (2014), Phelan (2015), and Gong and Phelan (2016a,b). Our paper adds to this work by studying the effect of collateral and financial innovation on global flows and international asset prices. In particular we work with a class of models, " $C$-models," introduced by Geanakoplos (2003).

Our paper is related to a large literature on how differences in financial systems drive capital flows. This "global imbalances" literature has tended to focus on how net capital flows arise between developed and developing countries. The literature has broadly considered differences in (i) state-completeness, (ii) the ability to supply financial assets, (iii) sharing idiosyncratic risk, and (iv) funding costs. In this literature, financial flows are driven primarily by interest rate (or investment return) differentials that manifest in different savings across countries. Financial integration leads to a convergence in savings levels and interest rates, and current account deficits can be financed indefinitely because the financially "deep" country earns intermediation rents.

Willen (2004) shows that market incompleteness across countries causes trade imbalances because superior risk-sharing in one country leads to a lower precautionary demand for saving. Caballero, Farhi and Gourinchas (2008) emphasize the role of heterogeneous

domestic financial systems in explaining global imbalances in which financial imperfections are captured by a country's ability to supply assets in a deterministic model. Their 
paper assumes that "Home" can supply more financial assets from real assets, which affects autarkic savings and interest rates, and the model can explain capital flows, current account deficits, and low interest rates.

Mendoza, Quadrini and Rios-Rull (2009) and Angeletos and Panousi (2011) have emphasized how net capital flows arise when the developed country can better insure idiosyncratic risk. Poor risk sharing increases buffer-stock savings and decreases autarkic interest rates. Within this literature, Phelan and Toda (2018) study how the risk-sharing qualities of securitized markets affect international capital flows, growth, and welfare, showing that capital flows from the high- to low-margin country. Maggiori (2017) provides a model in which Home financiers can take on greater financial risk as a result of funding advantages. This leads Home to run persistent current account deficits financed by the risk-premium earned by its financial sector, which can better absorb aggregate shocks.

While these interest rate and risk-sharing mechanisms are clearly important for understanding global flows and imbalances, we emphasize instead the role of collateral to facilitate gross flows, especially among developed countries. In our model, agents are risk-neutral, assets are identical, and interest rates do not change with financial integration (they are always zero). Flows are not driven by different savings demand. In our model all agents have identical savings demand, but agents have different portfolio demands. Instead, leverage and tranching create contingent securities from underlying collateral, and international trade allows investors to buy securities that are not available domestically. In our model, flows emerge because agents trade in underlying assets and not simply in a risk-free bond. Furthermore, our earlier observations suggest that focusing on net flows alone is insufficient, as the differentiation between gross inflows and outflows has become more important (Forbes and Warnock, 2012). While, in the early and mid 1990s net and gross flows used to move together, more recently the size and volatility of gross flows have increased while net capital flows have been more stable.

Finally, our focus on how financial integration leads to propagation and comovement is related to several theoretical papers. Caballero and Simsek (2016), who consider a model in which gross flows are driven by demands for liquidity (diversification) and the "fickle" 
reversal of capital flows creates instability. Flow reversals are assumed and the focus of the paper is on the implications for policy ex ante taking fickle flows as given. Mendoza and Quadrini (2010) extend the model in Mendoza, Quadrini and Rios-Rull (2009) (flows between U.S. and RoW driven by precautionary savings) to include financial intermediaries and study how financial integration affects the consequences of a one-time non-anticipated shock to intermediary capital. They find that shocks propagate as a result of financial integration; importantly, however, asset price declines are smaller than would be in autarky and the crisis would have been worse for the U.S. if it had not been financially integrated. In contrast, in our model price crashes are larger with financial integration, not in autarky. Theoretical work by Devereux and Yetman (2010) and Ueda (2012) present models, with financial intermediaries or with leverage constraints, in which financial integration affects spillovers, propagation through interdependent portfolios, and business-cycle synchronization.

\section{General Equilibrium Model with Collateral}

In this section we present a one-country $C$-model. We later use this architecture in an international two-country setting in Sections 4 and 5.

\section{Time, Commodities and Assets}

The model is a two-period general equilibrium model, with time $t=0,1$. Uncertainty is represented by a tree $S=\{0, U, D\}$ with a root $s=0$ at time 0 and two terminal states of nature $S_{T}=\{U, D\}$ at time 1 .

Let $L_{0}=\left\{c_{0}, Y\right\}, L_{U}=\left\{c_{U}\right\}, L_{D}=\left\{c_{D}\right\}$ be the set of commodities in states $0, U$ and $D$. Denote by $L_{T}=\cup_{s \in S_{T}} L_{s}$ the set of commodities in terminal states. Let $F_{S}\left(c_{0}, Y\right)=c_{0}+$ $d_{S} Y, s \in S_{T}$ be an inter-period production function connecting any vector of commodities at state $s=0$ with the vector of commodities it becomes in each state $s \in S_{T}$. As shown in Figure $1, c_{0}$ is a (perfectly) durable consumption good and $Y$ is physical risky asset, which produces dividends (in units of the consumption good) $d_{U}$ in state $U$ and $0<d_{D}<d_{U}$ in 


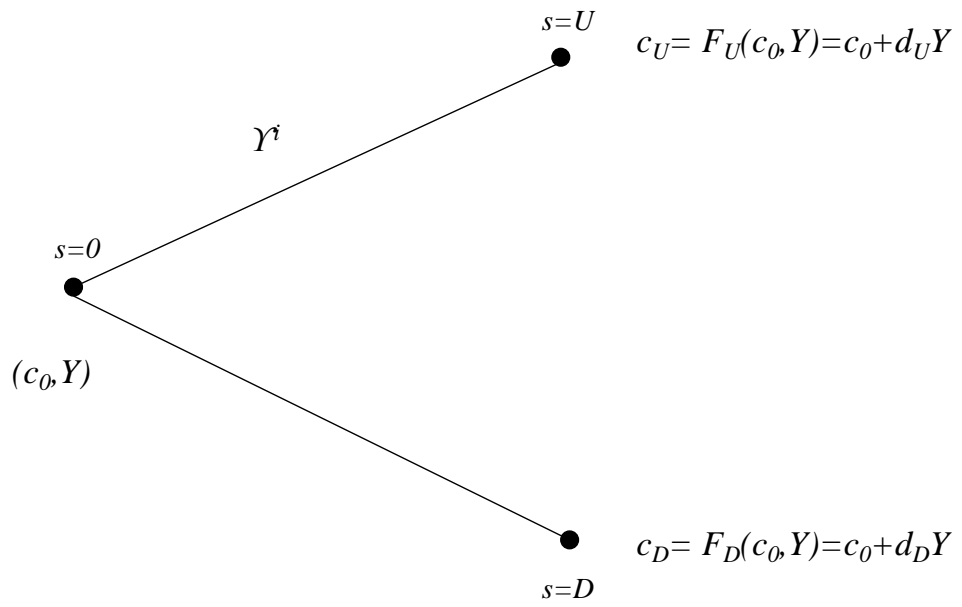

Figure 1: Time, commodities and assets.

state $D$.

We can always normalize one price in each state, so we take the price of $c_{s}$ in state $s \in S$ to be one. The price of the asset $Y$ at time 0 is denoted by $p$.

\section{Agents}

Agents are uniformly distributed in the continuum $I=[0,1]$ described by the Lebesgue measure. Each investor $i \in[0,1]$ is risk-neutral, does not discount the future, and consumes only at time 1 . The von-Neumann-Morgenstern expected utility to agent $i$ is

$$
U^{i}\left(c_{0}, Y, c_{U}, c_{D}\right)=\gamma_{U}^{i} c_{U}+\gamma_{D}^{i} c_{D}
$$

where $\left(\gamma_{U}^{i}, \gamma_{D}^{i}\right)=(\gamma(i), 1-\gamma(i))$ are the subjective probabilities. We suppose that $\gamma(i)$ is strictly increasing and continuous in $i$. Since only the output of $Y$ depends on the state and $0<d_{D}<d_{U}$, higher $i$ denotes more optimism. Heterogeneity among the agents stems entirely from the dependence of $\gamma(i)$ on $i$.

Each investor $i \in(0,1)$ has initial endowments of commodities at time 0 only, i.e. 
$e=\left(e_{c_{0}}, e_{Y}, e_{c_{U}}, e_{c_{D}}\right)=\left(e_{c_{0}}, e_{Y}, 0,0\right)$

\section{Financial Contracts and Collateral}

The heart of our analysis involves financial contracts and collateral. We explicitly incorporate repayment enforceability problems. ${ }^{14}$ Agents cannot be coerced into honoring their promises except by seizing collateral agreed upon by contract in advance.

A financial contract $j=\left(\left(j_{U}, j_{D}\right), 1_{Y}\right)$ consists of a promise $\left(j_{U}, j_{D}\right)$ of repayment in units of the consumption good at each future state, collateralized by one unit of $Y .{ }^{15} \mathrm{We}$ denote the total set of contracts by $J$.

The lender has the right to seize as much of the collateral as will make him whole once the promise comes due, but no more. Hence, the delivery of the contract is given by

$$
\left(\min \left(j_{U}, d_{U}\right), \min \left(j_{D}, d_{D}\right)\right)
$$

Each contract $j \in J$ trades at price $\pi_{j}$. We denote the sale of promise $j$ by $\varphi_{j}<0$ and the purchase of the same contract by $\varphi_{j}>0$. The sale of a financial contract corresponds to borrowing the sale price, $\pi_{j}$, and the purchase is tantamount to lending the same price in return for the promise. Whereas the sale of $\varphi_{j}<0$ contracts requires the ownership of $\varphi_{j}$ units of $Y$, the purchase of the same number of contracts does not require any ownership of $Y$.

\section{Budget Set}

Given asset and contract prices at time $0,\left(p,\left(\pi_{j}\right)_{j \in J}\right)$, each agent $i \in I$ chooses asset holdings $y$ of $Y$, contract trades $\varphi_{j}$ and consumption $c_{0}$ in state 0 , and consumption in final states $c_{U}, c_{D}$, in order to maximize utility (1) subject to the budget set defined by

\footnotetext{
${ }^{14} \mathrm{We}$ exclude collateral management problems. The value of the collateral in each future state does not depend on the size of the promise, or on what other choices the seller makes, or on who owns the asset at the very end. This eliminates any issues associated with hidden effort or unobservability. See Fostel and Geanakoplos $(2016,2015)$ for a discussion

${ }^{15}$ Restricting contracts to be collateralized by one unit of $Y$ is without loss of generality. A contract promising $(0.4,0.4)$ backed by two units of $Y$ is identical to two units of a contract promising $(0.2,0.2)$ backed by one unit of $Y$.
} 


$$
\begin{aligned}
B^{i}(p, \pi)=\{ & \left(c_{0}, y, \varphi, c_{U}, c_{D}\right) \in R_{+}^{L_{0}} \times R^{J} \times R_{+}^{L_{T}}: \\
& c_{0}+p y+\sum_{j \in J} \varphi_{j} \pi_{j} \leq e_{c_{0}}+p e_{Y}, \\
& \sum_{j \in J} \max \left(0,-\varphi_{j}\right) \leq y \\
& \left.c_{S}=F_{S}\left(c_{0}, Y\right)+\sum_{j \in J} \varphi_{j} \min \left(j_{s}, d_{s}\right), s \in S_{T}\right\} .
\end{aligned}
$$

At time 0 , total expenditures on the consumption good, the asset and financial contracts has to be financed by the value of initial endowments. The second constraint is the collateral constraint, which states that the total short position on financial contracts cannot exceed the total asset holdings required as collateral. Finally, consumption in the terminal states is derived from the receipts of storage, asset dividends and financial contracts net deliveries.

\section{Collateral Equilibrium}

A Collateral Equilibrium in this economy is a price of asset $Y$, contract prices, asset holdings, contract trades and consumption decisions by all the agents $\left((p, \pi),\left(c_{0}^{i}, y^{i}, \varphi^{i}, c_{U}^{i}, c_{D}^{i}\right)_{i \in I}\right) \in$ $\left(R_{+} \times R_{+}^{J}\right) \times\left(R_{+}^{L_{0}} \times R^{J} \times R_{+}^{L_{T}}\right)^{I}$, such that

1. $\int_{0}^{1} c_{0}^{i} d i=e_{c_{0}}$

2. $\int_{0}^{1} y^{i} d i=e_{Y}$

3. $\int_{0}^{1} \varphi_{j}^{i} d i=0 \forall j \in J$

4. $\left(c_{0}^{i}, y^{i}, \varphi^{i}, c_{U}^{i}, c_{D}^{i}\right) \in B^{i}(p, \pi), \forall i$

$\left(c_{0}, y, \varphi, c_{U}, c_{D}\right) \in B^{i}(p, \pi) \Rightarrow U^{i}\left(c_{0}, y, \varphi, c_{U}, c_{D}\right) \leq U^{i}\left(c_{0}^{i}, y^{i}, \varphi^{i}, c_{U}^{i}, c_{D}^{i}\right), \forall i$

In equilibrium, all markets clear and agents optimize their utilities in their budget sets. Geanakoplos and Zame (2014) show that, given our assumptions, equilibrium in this model always exists. 


\section{A Static Model of Global Flows}

We now consider a $C$-model with two countries, Home and Foreign (denoted by $*$ ), each defined as in Section 3. Both countries are identical in every way except for the feasible financial contracts available in each country, $J$ and $J^{*}$.

The key-and only-difference between the two countries is that Home has a more advanced financial system than Foreign. In our baseline model, we assume that Foreign assets can be used as collateral to issue non-contingent financial promises (i.e., collateralized debt). In other words, Foreign assets can be leveraged. In contrast, we consider a more sophisticated use of $Y$ as collateral by the Home financial sector: Home assets can be used as collateral to issue state-contingent financial promises. In other words, the risky Home asset can be tranched into state-contingent promises. ${ }^{16}$ This feature intends to capture the advanced ability of the U.S. financial system to securitize and tranche mortgages and other financial assets.

Financial systems differ in a myriad of both subtle and complex ways (for example, the level of insurance and risk sharing) but the salient features that we are focusing on are the ability to leverage, securitize, and tranche assets, which is reflected in the financial structures we assume. We model investors as directly borrowing against assets, but these trades could also capture the role of financial intermediaries in producing the financial assets that correspond to these cash flows. We return to this distinction in Section 4.3.

The main insight from the static analysis is that differences in the ability to collateralize financial promises across borders are enough to generate gross international financial flows. In our model, financially integrated countries have access to the same set of financial instruments: there are no interest rate differentials (e.g., arising from differences in precautionary savings), nor hedging or risk-sharing motives to trade assets (agents are risk-neutral and assets have identical payoffs). International trade in financial assets is

\footnotetext{
${ }^{16}$ In Appendix D we also consider when Foreign assets cannot be used as collateral at all, and when Home can either leverage or tranche assets. This model with no leverage in Foreign presents many similar intuitions, mechanisms, and insights that are present in the richer model with leverage and tranching. The model when Home can leverage provides insights corresponding to trade between developed and developing countries.
} 
a way to internationally share scarce collateral. Furthermore, the autarkic cross-country price differential of assets with identical payoffs not only persists but gets larger after financial integration. Finally, Home always run a current account deficit financed by trade in more expensive financial assets.

We first describe autarkic equilibria in each country and then describe the equilibrium with financial integration. As a way of developing intuition before presenting the theoretical results, we numerically solve for the equilibrium in each case for the following parameters: agents' utilities and endowments in both countries are given by $\gamma(i)=1-(1-i)^{2}$, $e_{Y}=e_{c_{0}}=1$, and asset payoffs in both countries are given by $d_{U}=1$ and $d_{D}=0.2$.

\subsection{Foreign Autarky: Leverage}

In autarky, the Foreign financial sector can issue non-contingent promises using the asset as collateral. In this case $J^{*}=\left\{j: j=\left((j, j), 1_{Y}\right)\right\}$. Each debt contract promises $j$ at $t=1$, and is collateralized by one unit of the asset. When selling contract $j$ an investor borrows $\pi_{j}$ at $t=0$. Hence, by purchasing $Y^{*}$ and selling any contract $j$, Foreign agents can leverage their purchases of assets.

Leverage is endogenous in the model: agents choose which contracts to trade, taking their prices as given. All contracts are priced in equilibrium, however, since collateral is scarce, only a few of them (or even just one) may be actively traded. Fostel and Geanakoplos (2012b) show that in $C$-models the only contract actively traded is the "maxmin" contract $j^{*}=\min _{s=U, D}\left\{d_{s}\right\}=d_{D}$, with an associated price $\pi^{*}=d_{D}$ (so the risk-free interest rate is zero), ruling out default in equilibrium. Notice that when agents leverage asset $Y^{*}$ by selling the maxmin contract $j^{*}=d_{D}$, they are effectively buying the Arrow $U^{*}$ security, since, per unit of asset they leverage with the maxmin contract, they consume $d_{U}-d_{D}$ in the state $U$ and $d_{D}-d_{D}=0$ in state $D$.

With this result in hand, equilibrium in this economy is easy to characterize. In equilibrium there is a marginal buyer $i_{1}^{*}$, who is indifferent between leveraging $Y^{*}$ and holding the consumption good $c^{*}{ }^{17}$ All agents $i>i_{1}^{*}$ buy all the $Y^{*}$ in the economy with leverage:

\footnotetext{
${ }^{17}$ This is because of the linear utilities, the continuity of utility in $i$ and the connectedness of the set of
} 


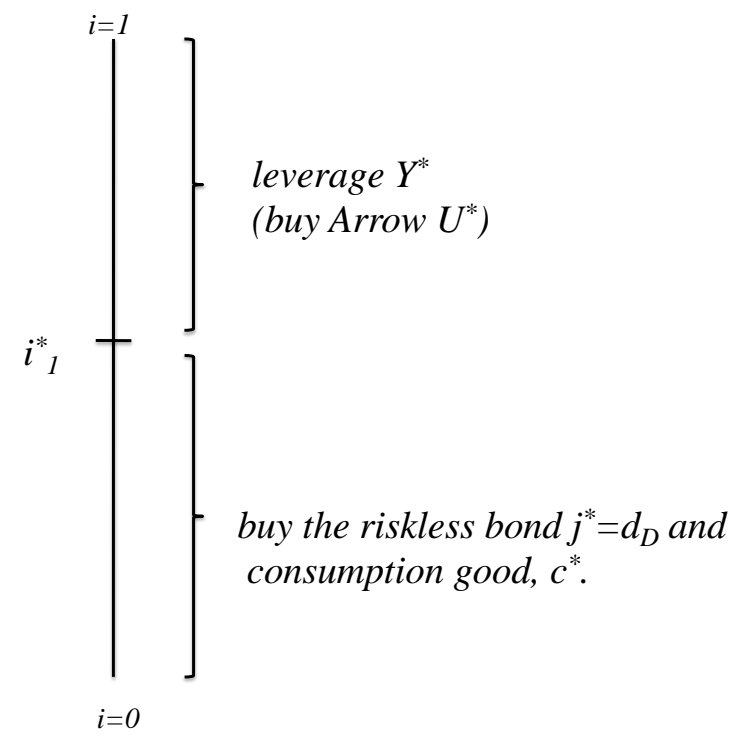

Figure 2: Equilibrium regime in Foreign autarky.

they borrow $d_{D}$ by selling debt contract $j^{*}=d_{D}$ using $Y^{*}$ as collateral (effectively buying the Arrow $U^{*}$ security). Agents $i<i_{1}^{*}$ lend to the more optimistic investors, holding the durable consumption good and the risk-free debt $j^{*}=d_{D}$. This regime can be seen in Figure 2. Equilibrium is described by a system of two equations in two unknowns, $p^{*}$ and $i_{1}^{*}:$

$$
\begin{gathered}
e_{Y^{*}}=\left(1-i_{1}^{*}\right) \frac{\left(e_{c_{0}}+e_{Y^{*}} p^{*}\right)}{p^{*}-d_{D}}, \\
p^{*}=\gamma\left(i_{1}^{*}\right) d_{U}+\left(1-\gamma\left(i_{1}^{*}\right)\right) d_{D} .
\end{gathered}
$$

Equation (3) corresponds to the market clearing condition for the $Y^{*}$ market. ${ }^{18}$ The top $1-i_{1}^{*}$ agents are leveraging the asset. Each of the agents is spending the total value of their initial endowment of $e_{c_{0}}+e_{Y^{*}} p^{*}$ on the downpayment, $p^{*}-d_{D}$. Their aggregate demand has to equal the aggregate supply of $e_{Y^{*}}$. Paying only the downpayment $p^{*}-d_{D}$, as opposed to the full price, allows a relatively small fraction of agents to buy all the asset in the economy - certainly fewer than would be required if no borrowing were allowed. ${ }^{19}$

agents $I$.

${ }^{18}$ The risk-free market (consumption good and the riskless bond) clears by Walras' Law.

${ }^{19}$ See Appendix D for an analysis of this case. 
Equation (4) states that the asset is priced according to the marginal buyer's beliefs. ${ }^{20}$ Notice that equation (4) can also be written as $1=\frac{\gamma\left(i_{1}^{*}\right)\left(d_{U}-d_{D}\right)}{p^{*}-d_{D}}$, where the right-hand side is the return of the leveraged position (or the return of a Arrow $U^{*}$ ). For the parameters above, equilibrium is given by $i_{1}^{*}=0.63$ and $p^{*}=0.89$.

\subsection{Home Autarky: Tranching}

We suppose that $J$ consists of the single contingent promise $j_{T}=\left(\left(0, d_{D}\right), 1_{Y}\right)$, a "downtranche." Notice that when buying $Y$ and using it as collateral to issue the down-tranche, an agent completely tranches the asset payoffs into Arrow securities. The seller, is effectively buying an Arrow $U$ security that pays $\left(d_{U}, 0\right)$, and the buyer of the tranche is effectively buying an Arrow $D$ security that pays $\left(0, d_{D}\right) \cdot{ }^{21}$

The equilibrium at Home is also simple to characterize. It features two marginal buyers, $i_{2}<i_{1}$. Optimistic agents $i>i_{1}$ buy all the $Y$ in the economy and use it as collateral to sell the down tranche $j_{T}=\left(0, d_{D}\right)$, effectively holding an Arrow $U$ security. Moderate agents $i \in\left[i_{2}, i_{1}\right]$ hold the consumption good. Finally, the most pessimistic agents $i<i_{2}$ buy the down tranche $j_{T}=\left(0, d_{D}\right)$ from the most optimistic investors, effectively buying an Arrow $D$ security. The equilibrium regime is presented in Figure 3.

In this case, equilibrium is described by a system of four equations and four unknowns: the price of the asset, $p$, the price of the down tranche, $\pi_{T}$, and the two marginal buyers, $i_{1}$ and $i_{2}$. Equations (5) and (6) are the market clearing conditions for the asset $Y$ and the tranche $j_{T}$ :

$$
\begin{gathered}
e_{Y}=\left(1-i_{1}\right) \frac{\left(e_{c_{0}}+e_{Y} p\right)}{p-\pi_{T}}, \\
e_{Y}=i_{2} \frac{\left(e_{c_{0}}+e_{Y} p\right)}{\pi_{T}}
\end{gathered}
$$

The top $1-i_{1}$ agents buy the asset and sell off the down tranche: they each have wealth

\footnotetext{
${ }^{20}$ The marginal buyer is indifferent between the leveraged position and holding a riskless position. Hence the ratio of prices must equal the ratio or marginal utilities. Both, the price of the consumption good and its marginal utility are one, yielding equation (4).

${ }^{21}$ Considering this single promise is without loss of generality. See Fostel-Geanakoplos (2015) and Geanakoplos-Zame (2014).
} 


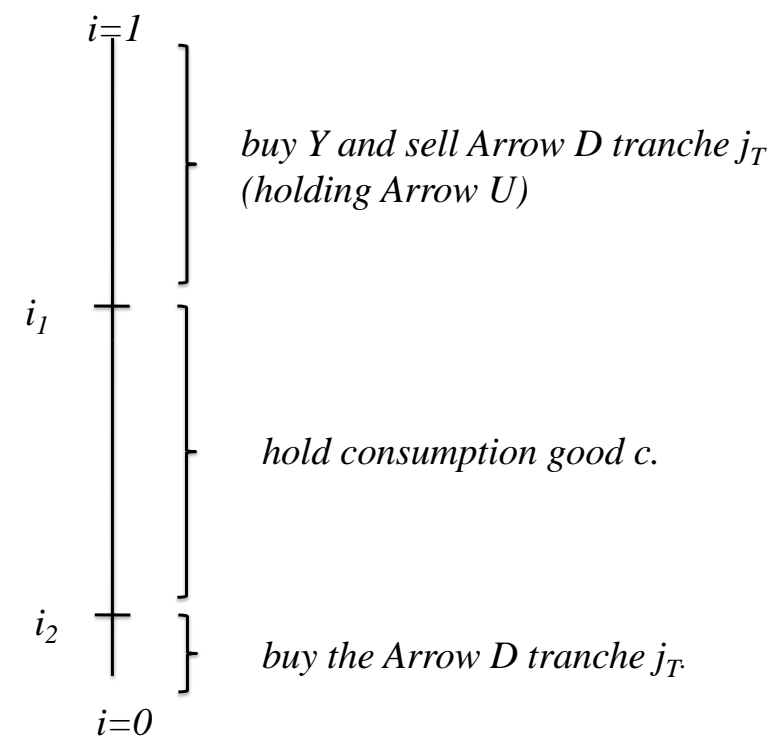

Figure 3: Equilibrium regime in Home autarky.

$e_{c_{0}}+e_{Y} p$ that they spend solely on the downpayment $p-\pi_{T}$; their aggregate demand must equal the aggregate supply of $e_{Y}$. Analogously, the aggregate demand for tranches from the bottom $i_{2}$ agents has to equal the aggregate supply of down tranche of $e_{Y}$. Equations (7) and (8) are the optimality conditions:

$$
\begin{gathered}
\frac{\gamma\left(i_{1}\right) d_{U}}{p-\pi_{T}}=1, \\
\frac{\left(1-\gamma\left(i_{2}\right)\right) d_{D}}{\pi_{T}}=1 .
\end{gathered}
$$

Equation (7) states that the marginal buyer $i_{1}$ is indifferent between the return from tranching the asset (buying the asset and selling the down tranche) and the return from holding the consumption good. Equation (8) states that the marginal buyer $i_{2}$ is indifferent between the return from the down tranche and the return from holding the consumption good. Equations (7) and (8) imply that the two marginal buyers determine the price of the Arrow securities independently: $i_{1}$ sets the price of the Arrow $U$ and $i_{2}$ the price of the 
Arrow $D .^{22}$

For the same parameter values, in equilibrium $p=1, \pi_{T}=0.17, i_{1}=0.58$ and $i_{2}=$ 0.08. The asset price of the risky asset at Home is much higher than in the Foreign country. This is a general property of $C$-models when beliefs are concave, as in our numerical example (see Fostel-Geanakoplos (2012)). Note also that the price of the asset is higher than any agent $i<1$ believes can be justified by the fundamentals (if $d_{D}>0.2$ then the price $p$ would exceed 1, implying no agent believes fundamentals justify the price). Tranching generates bubbles; we will return to this point in the next section.

\subsection{Financial Integration}

With financial integration (FI), Home and Foreign agents have access to the same set of financial instruments. We denote equilibrium variables after financial integration by a 'hat' $\left.{ }^{\wedge}\right)$ to distinguish them from their autarkic counterparts.

In the FI equilibrium the marginal investors across countries are the same because the assets have identical payoffs and agents have the same endowments and preferences. In each country there are two common marginal investors: $\hat{i}_{1}>\hat{i}_{2}$. Optimistic agents in both countries $i \geq \hat{i}_{1}$ tranche $Y$ and leverage $Y^{*}$, effectively holding the Arrow $U$ and Arrow $U^{*}$ securities. Moderate investors $\hat{i}_{2}<i<\hat{i}_{1}$ hold consumption goods $c$ and $c^{*}$, and riskless bonds $j^{*}=d_{D}$. Finally, pessimistic investors $i \leq \hat{i}_{2}$ buy the down tranche from the most optimistic agents (hence holding an Arrow D). This regime is shown in Figure 4.

Equilibrium is described by a system of five equations in five unknowns: the prices of the assets, $\hat{p}^{*}$ and $\hat{p}$, the price of the tranche, $\hat{\pi}_{T}$, and the marginal buyers, $\hat{i}_{1}$ and $\hat{i}_{2}$. The first two equations are the market clearing conditions. Equation (9) is the market clearing condition for $Y$ and $Y^{*}$ :

$$
\left(1-\hat{i}_{1}\right) \frac{\left(2 e_{c_{0}}+e_{Y}\left(\hat{p}+\hat{p}^{*}\right)\right)}{\hat{p}+\hat{p}^{*}-\left(\hat{\pi}_{T}+d_{D}\right)}=e_{Y}
$$

\footnotetext{
${ }^{22}$ Despite the fact that both Arrow securities can be created through tranching the asset, markets are not complete because Arrow securities are created through the asset only, and collateral equilibrium fails to implement the Arrow-Debreu equilibrium.
} 


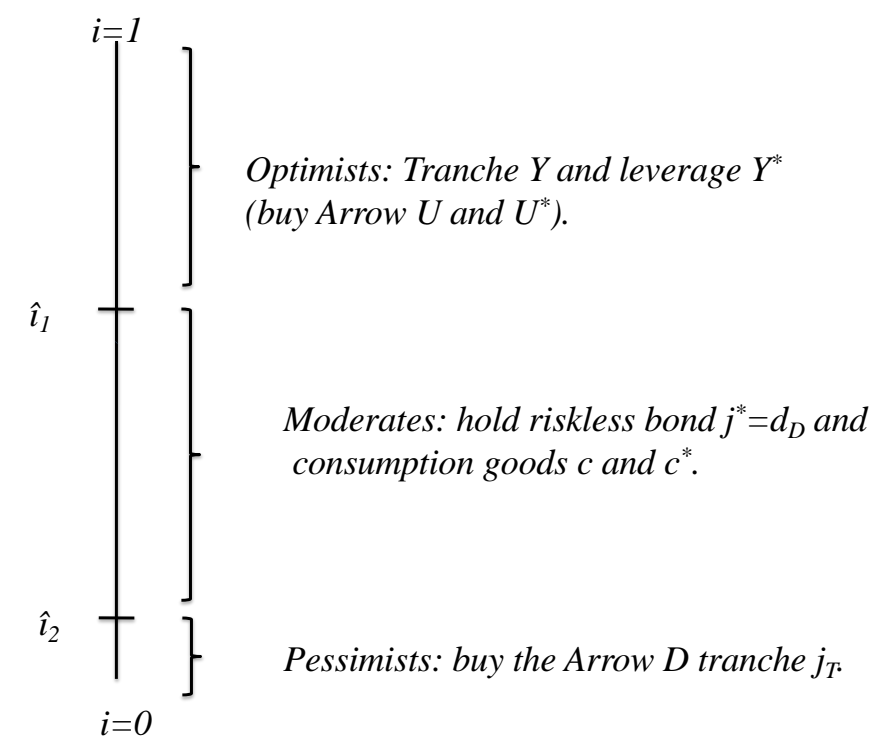

Figure 4: Equilibrium regime in financial integration.

Equation (10) corresponds to market clearing for the down tranche:

$$
\hat{i}_{2} \frac{\left(2 e_{c_{0}}+e_{Y}\left(\hat{p}+\hat{p}^{*}\right)\right)}{\hat{\pi}_{T}}=e_{Y} .
$$

Compared to their autarky counterparts (equations (3), (5) and (6)), the market clearing conditions in FI include wealth from both countries $\left(2 e_{c_{0}}+e_{Y}\left(\hat{p}+\hat{p}^{*}\right)\right){ }^{23}$

The last three equations are no-arbitrage and optimality conditions. Equation (11) states that by no-arbitrage, the return from tranching $Y$ (that creates an Arrow $U$ ) and leveraging $Y^{*}$ (that creates and Arrow $U^{*}$ ) should be the same:

$$
\frac{d_{U}}{\hat{p}-\hat{\pi}_{T}}=\frac{d_{U}-d_{D}}{\hat{p}^{*}-d_{D}}
$$

\footnotetext{
${ }^{23}$ For example in the case of the down tranche market, investors will buy $\frac{1}{\hat{\pi}_{T}}$ units of the tranche for every unit of wealth. Home investors have wealth $1+\hat{p}$ and Foreign investors have wealth $1+\hat{p}^{*}$. Since all investors $i \leq \hat{i}_{2}$ in each country buy the down tranche, the total global demand for down tranches is given by

$$
\int_{0}^{\hat{i}_{2}}\left(\frac{e_{c_{0}}+e_{Y} \hat{p}}{\hat{\pi}_{T}}\right) d i+\int_{0}^{\hat{i}_{2}}\left(\frac{e_{c_{0^{*}}}+e_{Y^{*}} \hat{p}^{*}}{\hat{\pi}_{T}}\right) d i=\hat{i}_{2}\left(\frac{2 e_{c_{0}}+e_{Y}\left(\hat{p}+\hat{p}^{*}\right)}{\hat{\pi}_{T}}\right) .
$$

Notice that we are assuming that countries are identical in everything except the set $J$, and we are hence using the fact that endowments are the same in the above equation.
} 
Equation (12) states that the marginal buyer $\hat{i}_{1}$ is indifferent between an Arrow $U$ (through either tranching the Home asset or leveraging the Foreign asset) and a safe position (either holding consumption goods or the riskless bonds):

$$
\frac{\gamma\left(\hat{i}_{1}\right) d_{U}}{\hat{p}-\hat{\pi}_{T}}=1 .
$$

Equation (13) states that the marginal buyer $\hat{i}_{2}$ is indifferent between the down tranche and a safe position (either holding consumption goods or the riskless bonds):

$$
\frac{\left(1-\gamma\left(\hat{i}_{2}\right)\right) d_{D}}{\hat{\pi}_{T}}=1 .
$$

\subsubsection{Financial Integration and Asset Prices}

One would expect the price difference between two assets with identical payoffs to disappear once integration is allowed, but instead we observe that the difference increases. Table 1 shows the equilibrium prices and marginal buyers.

Table 1: Equilibrium with financial integration.

\begin{tabular}{l|cc}
\hline & Autarky & Financial Integration $\left(^{\wedge}\right)$ \\
\hline$p^{*}$ & 0.893 & 0.878 \\
$p$ & 1 & 1.029 \\
$\pi_{T}$ & 0.168 & 0.182 \\
$i_{1}^{*}$ & 0.63 & 0.61 \\
$i_{1}$ & 0.58 & 0.61 \\
$i_{2}$ & 0.084 & 0.047
\end{tabular}

First, financial integration increases the price of the Home asset $Y$, it goes from 1 to 1.029. Notice that from equations (12) and (13) we have that

$$
\hat{p}=\gamma\left(\hat{i}_{1}\right) d_{U}+\left(1-\gamma\left(\hat{i}_{2}\right)\right) d_{D}
$$

With financial integration pessimistic Foreign investors demand down tranches (contingent promises that were previously unavailable). Hence their price increases from 0.168 to 0.182 , and the marginal buyer that prices the tranche, $i_{2}$, decreases (going from 0.084 in 
autarky to 0.047 in FI). Moreover, because buyers of $Y$ can now issue a more expensive tranche, fewer optimists are required to buy up all of $Y$, and so the marginal buyer, $i_{1}$, increases, rising from 0.58 in autarky to 0.61 in FI. Both of these effects cause the price of $Y$ to increase given equation (14).

Second, financial integration decreases the price of $Y^{*}$, which goes from 0.893 to 0.878 (notice that the marginal buyer, $i_{1}$, has decreased from 0.63 in autarky to 0.61 in FI). This is because the attractiveness of alternative investments increases. With financial integration, investors in the Foreign asset compare investing in the asset to a tranched return in the Home asset, as shown by equation (11), rather than simply a safe position, as was the case in autarky.

The effect of financial innovation on asset prices just described in our numerical example is a general property stated in the following proposition.

\section{Proposition 1:}

Consider a $C$-model with two countries Home and Foreign as in Section 3. Then $\hat{p}^{*}<p^{*}$ and $\hat{p}>p$ : financial integration increases the Home asset price and decreases the Foreign asset price.

Proof: see Appendix A.

Trade occurs, despite the identical assets' payoffs in both economies, because assets have different collateral capacities. The Home asset $Y$ is better collateral: $Y$ can be tranched into state-contingent promises whereas $Y^{*}$ can only be used to issue debt. One would expect the price difference to disappear between two assets with identical payoffs once integration is allowed, but instead we observe that the difference increases as we showed in Proposition 1. This represents a deviation from the Law of One Price due to the presence of different collateral values in equilibrium. This can be easily seen in our numerical example. Consider the optimistic agent $i=0.9$. Her marginal utility of money (the best use of a dollar at time 0 ), $\mu^{0.9}$ is given by

$$
\mu^{0.9}=\frac{\gamma_{U}(0.9) d_{U}}{\hat{p}-\hat{\pi}_{T}}=\frac{0.99(1)}{1.029-0.182}=1.17
$$

Hence, tranching $Y$ provides 1.17 utiles per dollar of down payment. 
Consider first the Home asset. $Y$ has a collateral value beyond its payoff value. We can measure these in dollar equivalents as follows. The Payoff Value of $Y$ for agent $i=0.9$ is given by the marginal utility of $Y$ measured in dollar equivalents, or $P V_{Y}^{0.9}=$ $\frac{0.99(1)+0.01(0.2)}{\mu^{0.9}}=0.85<\hat{p}$. The Collateral Value of $Y$ for agent $i=0.9$ is given by the difference between the price and the payoff value, $C V_{Y}^{0.9}=\hat{p}-P V_{Y}^{0.9}=1.029-0.85=0.18$. Consider next the Foreign asset $Y^{*}$, which also has a collateral value, but lower. Since the payoffs are identical the payoff value is the same as for $Y, P V_{Y^{*}}^{0.9}=\frac{0.99(1)+0.01(0.2)}{\mu^{0.9}}=$ $0.85<\hat{p}^{*}$. The Collateral Value of $Y^{*}$ for agent $i=0.9$ is given by $C V_{Y^{*}}^{0.9}=\hat{p}^{*}-P V_{Y^{*}}^{0.9}=$ $0.87-0.85=0.03$. With a continuum of investors, the economy features a continuum of investor-specific collateral values, but the collateral value will always be positive for every agent $i>\hat{i}_{1}=0.61 .^{24}$

Let us define the price gap between the Home and Foreign asset prices in equilibrium as $\hat{\Delta}=\hat{p}-\hat{p}^{*}$. Since both assets have identical payoffs and hence payoffs values, this exactly represents the equilibrium gap in collateral values. ${ }^{25}$ The following proposition provides a useful characterization of $\hat{\Delta}$ and shows that it is always positive.

\section{Proposition 2:}

Consider a $C$-model with two countries Home and Foreign as in Section 3. Then $\hat{\Delta}=d_{D}\left(\gamma\left(\hat{i}_{1}\right)-\gamma\left(\hat{i}_{2}\right)\right)>0$ : the Home asset price always exceeds the Foreign asset price.

Proof:

From equations (11), (12), and (13), we can write asset prices as

$$
\begin{aligned}
\hat{p} & =\gamma\left(\hat{i}_{1}\right) d_{U}+\hat{\pi}_{T}=\gamma\left(\hat{i}_{1}\right) d_{U}+\left(1-\gamma\left(\hat{i}_{2}\right)\right) d_{D}, \\
\hat{p}^{*} & =\gamma\left(\hat{i}_{1}\right)\left(d_{U}-d_{D}\right)+d_{D} .
\end{aligned}
$$

Hence we have $\Delta=d_{D}\left(\gamma\left(\hat{i}_{1}\right)-\gamma\left(\hat{i}_{2}\right)\right)$, which is positive since $\hat{i}_{1}>\hat{i}_{2}$ and beliefs are monotonic.

In what follows, we show that this positive collateral gap has important implications for net and gross flows.

\footnotetext{
${ }^{24}$ See Fostel-Geanakoplos (2008).

${ }^{25}$ Although the collateral value is investor specific, the gap in collateral values is not.
} 


\subsubsection{Financial Integration, Gross Flows and the Current Account}

Determining the portfolio holdings and flows in the FI equilibrium requires some care, since there are many securities that are perfect substitutes: the Arrow $U$ and Arrow $U^{*}$ (created by tranching $Y$ or leveraging $Y^{*}$ respectively), consumption goods $c, c^{*}$ and the riskless bond $j=d_{D}$. We are going to use the fact that the regimes are the same in both countries, and pin down the holdings by assuming that each country holds the same proportion of everything. ${ }^{26}$

Holdings and flows are nominal. More specifically, for any security $x$, with price $p_{x}$ and supply $S_{x}$, the value of Home holdings and Foreign holdings are given by:

$$
V_{x}=\delta S_{x} p_{x}, V_{x}^{*}=\delta^{*} S_{x} p_{x}
$$

where:

$$
\delta=\frac{\left(e_{c_{0}}+e_{Y} \hat{p}\right)}{2 e_{c_{0}}+e_{Y}\left(\hat{p}+\hat{p}^{*}\right)}, \delta^{*}=\frac{\left(e_{c_{0^{*}}}+e_{Y^{*}} \hat{p}^{*}\right)}{2 e_{c_{0}}+e_{Y}\left(\hat{p}+\hat{p}^{*}\right)},
$$

represent the weight, given by the ratio between domestic and international wealth.

The first way to describe international flows, shown in Figure 5, is in the space of original commodities: collateral $Y$ and $Y^{*}$ and consumptions goods $c$ and $c^{*}$.

Optimistic Foreign agents buy $V_{Y}^{*}=0.49$ worth of Home assets and optimistic Home agents buy $V_{Y^{*}}=0.46$ worth of Foreign assets. The real counterpart of these financial flows are that Foreign moderate agents buy $V_{c}^{*}=0.48$ worth of the Home consumption good, whereas Home moderate investors buy $V_{c^{*}}=0.51$ worth of the Foreign consumption good. As a result $V_{Y}^{*}-V_{Y^{*}}=V_{c^{*}}-V_{c}^{*}=0.03 .{ }^{27}$ Home runs a current account deficit financed by the difference in value of gross flows in assets serving as collateral.

In this first interpretation, countries trade in assets and use them as collateral to issue

\footnotetext{
${ }^{26}$ This is a very standard criteria, these holdings would arise in CAPM for example. Additionally, these holdings would arise if Foreign assets were subject to even the smallest borrowing friction (e.g., constraint on promises below $d_{D}$ ). We could have chosen other criteria taking into account home bias, etc. Since this is not a quantitative exercise, the precise way of doing it is not so relevant. Qualitative results, in terms of direction of predicted flows, are unchanged.

${ }^{27}$ Our model features a current account financed by the sales of assets, even though the economy features no inter-temporal substitution.
} 


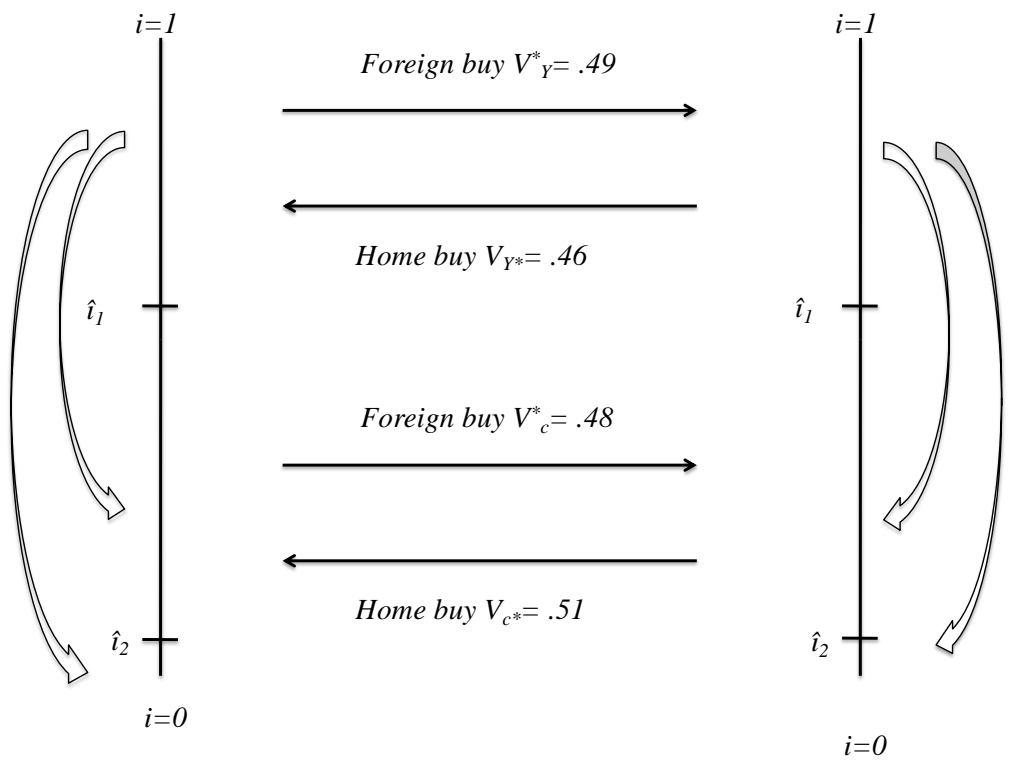

Figure 5: International flows. First interpretation.

financial promises domestically. Home buys the foreign asset and leverages it by issuing riskless bonds domestically, and Foreign buys the home asset and tranches it by selling down tranches domestically.

A second way to describe international flows is in the space of derivatives created by collateralized contracts. This second interpretation emphasizes that the source of different collateral capacities across assets resides in domestic institutions: only financial institutions at Home can tranche the risky asset. This may be due to a more advanced court system, etc. In this second view, there is a financial intermediary, that makes zero profits in equilibrium, tranching the asset at Home (and leveraging the asset in the Foreign country). Hence, we can think of international trade in derivatives and consumption goods directly. As shown in Figure 6, optimistic Foreign agents buy $V_{U}^{*}=0.41$ of Arrow $U$ securities whereas pessimistic Foreign agents buy $V_{D}^{*}=0.09$ Down tranches, both created using the $Y$ asset as collateral. Optimistic Home agents buy $V_{U^{*}}=0.35$ of Arrow $U^{*}$ tranches and moderate Home agents buy $V_{B^{*}}=0.10$ of the riskess bond, both created through leveraging the $Y^{*}$ asset. As before, net trade in goods (current account) equals the difference in value of gross financial flows, so $V_{U}^{*}+V_{D}^{*}-\left(V_{U^{*}}+V_{B^{*}}\right)=V_{c^{*}}-V_{c}^{*}=0.03$. 


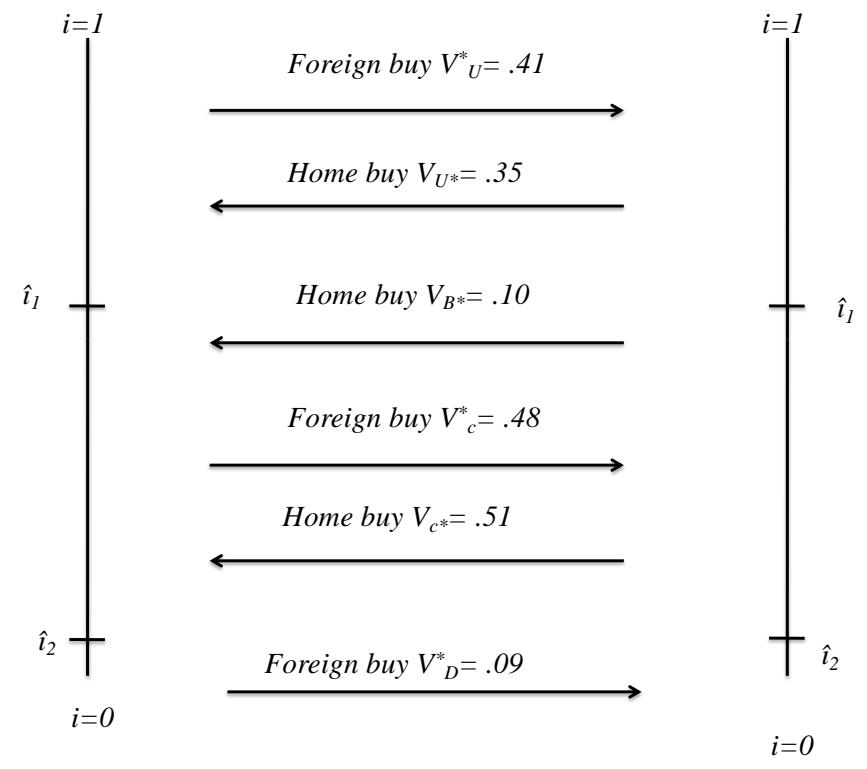

Figure 6: International flows. Second interpretation.

Note that, while the down tranche is a state-contingent security (and therefore very risky), the creation of down tranches could also be interpreted as the creation of "safe assets," which as it turns out tend to increase in value in bad states of the world: negativebeta assets are truly safe assets. ${ }^{28}$

The fact that Home runs a current account deficit financed by the sale of expensive derivatives created through collateral is a general property of our model, as the following proposition states.

\section{Proposition 3:}

Consider a $C$-model with two countries Home and Foreign as in Section 3. Then Home always runs a current account deficit that is proportional to the collateral gap. That is,

$$
C A=V_{c^{*}}-V_{c}^{*}=\frac{e_{Y} \hat{\Delta}}{2 e_{c_{0}}+e_{Y}\left(\hat{p}+\hat{p}^{*}\right)} .
$$

\footnotetext{
${ }^{28}$ First, long-maturity bonds increase in price in bad states because long-term interest rates decline (even as the face value of the promised payoffs remain the same). Second, because the U.S. Dollar tends to appreciate during crises, dollar-denominated bonds provide a natural hedge for foreign buyers. This is a point made in Maggiori (2017), which, in a different financial context, describes the rest of the world buying "down state" Arrow securities from Home in order to achieve safer portfolios.
} 
Proof:

Let $V_{c^{*}}$ and $V_{c}^{*}$ denote the value of Home purchases of $c^{*}$ and Foreign purchases of $c$ :

$$
V_{c^{*}}=\frac{\left(e_{c_{0}}+e_{Y} \hat{p}\right)}{2 e_{c_{0}}+e_{Y}\left(\hat{p}+\hat{p}^{*}\right)}, V_{c}^{*}=\frac{\left(e_{c_{0^{*}}}+e_{Y^{*}} \hat{p}^{*}\right)}{2 e_{c_{0}}+e_{Y}\left(\hat{p}+\hat{p}^{*}\right)}
$$

Hence we have that:

$$
V_{c^{*}}-V_{c}^{*}=\frac{\left(e_{c_{0}}+e_{Y} \hat{p}\right)}{2 e_{c_{0}}+e_{Y}\left(\hat{p}+\hat{p}^{*}\right)}-\frac{\left(e_{c_{0^{*}}}+e_{Y^{*}} \hat{p}^{*}\right)}{2 e_{c_{0}}+e_{Y}\left(\hat{p}+\hat{p}^{*}\right)}=\frac{e_{Y} \hat{\Delta}}{2 e_{c_{0}}+e_{Y}\left(\hat{p}+\hat{p}^{*}\right)} .
$$

By Proposition 2, Home always runs a current account deficit.

\subsubsection{Comparative Statics and Low Tail Risk}

Since a key driver of flows is the collateral gap $\hat{\Delta}$, which from Proposition 2 can be written as $\hat{\Delta}=d_{D}\left(\gamma\left(\hat{i}_{1}\right)-\gamma\left(\hat{i}_{2}\right)\right)>0$, flows are generally greater when the payoff in the down state $d_{D}$ is greater, reflecting a greater collateral capacity of both assets as well as a greater distinction between debt and down tranches. Our model implies that gross and net flows increase as collateral capacity increases. Figure 7 plots asset prices and flow values as a function of the downside risk $d_{D}$. Both $\hat{p}$ and $\hat{p}^{*}$ are increasing in $d_{D}$, and so is the collateral gap $\hat{\Delta}$. Accordingly, gross flows are larger the higher is $d_{D}$, as are net flows. ${ }^{29}$

\section{A Dynamic Model of Global Flows}

The static model in Section 4 illustrates how financial integration affects prices and creates cross-border flows. In this section we use a three-period variation of the $C$-model introduced in Section 3, with bad news arriving at an interim date, to consider the effect of financial integration on volatilities of flows and prices.

\footnotetext{
${ }^{29}$ These results are robust to varying beliefs, including allowing beliefs to be substantially convex. Since varying the down payoff mechanically increases the expected payoff of both assets, we have also considered the same comparative static varying $d_{D}$ while also varying beliefs so that the expected payoff to each agent remains the same even as the down payoff varies. To do so, we set a base down payoff of $\bar{R}=0.2$ and define modified beliefs by $\tilde{\gamma}\left(i ; d_{D}\right)=\frac{\bar{y}(i)-d_{D}}{1-d_{D}}$, where $\bar{y}(i)$ is the expected asset payoff for person $i$ when $d_{D}=\bar{R}$. Correcting in this way, the results are in fact even stronger.
} 

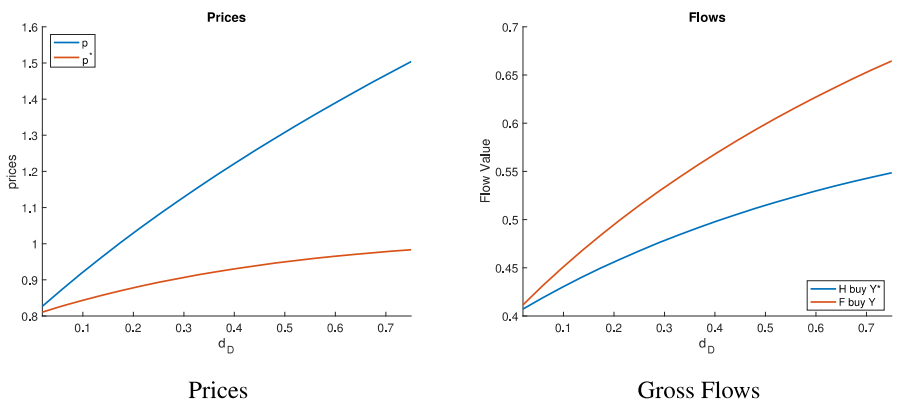

Figure 7: Comparative statics and low tail risk.

Our dynamic analysis shows that financial integration amplifies price volatility of both Home and Foreign assets, thus increasing global volatility. Moreover, capital flows dry up after bad news.

Consistent with Observation 2 in the Introduction, our results highlight that financial integration amplifies financial shocks and exports volatility across countries. Thus, in the presence of other shocks (trade, import prices, productivity, etc.), financial shocks become more significant given the higher volatility, and so financial shocks will tend to transmit through financial integration.

\subsection{Dynamic Model}

The model is a three-period general equilibrium model, with time $t=0,1,2$. Uncertainty is represented by a tree $S=\{0, U, D, U U, D U, D D\}$, illustrated in Figure 8, with a root $s=0$ at time 0 and terminal states $S_{T}=\{U U, D U, D D\}$ at time 2 . Denote by $s^{*}$ the unique predecessor of state $s$.

Let $L_{s}=\left\{c_{s}, Y_{s}\right\}$ be the set of commodities in each non-terminal state $s \in\{0, U, D\}$, and $L_{s}=\left\{c_{s}\right\}$ the set of commodities in terminal states $s \in S_{T}$. Let the inter-period production functions be as $F_{S}\left(c_{0}, Y\right)=\left(c_{0}, Y\right), s=U, D$, (i.e., consumption and the asset $Y$ are durable) and $F_{S}\left(c_{s^{*}}, Y_{s^{*}}\right)=c_{s^{*}}+d_{S} Y_{s^{*}} S \in S_{T}$. As in the static model, the consumption good is perfectly durable and the assets only pay dividends in units of the consumption good in the terminal states. In the numerical simulation that follows we assume that $d_{U U}=d_{D U}=1$ and $d_{D D}=0.2$. This type of uncertainty, introduced by Geanakoplos (2003), is character- 


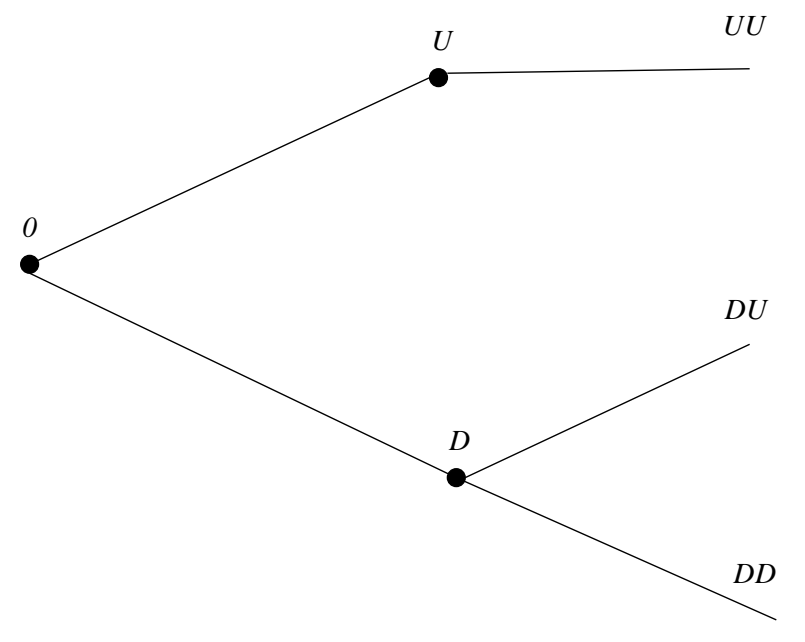

Figure 8: Dynamic $C$-model.

ized by increases in volatility after interim bad news. ${ }^{30}$

As before, we take the price of $c_{s}$ in state $s \in S$ to be one. The price of the asset $Y$ at non-terminal nodes is denoted by $p_{s}$.

Consider the same type of agents as in Section 3 with von-Neumann-Morgenstern expected utility as

$$
U^{i}=i c_{U U}+i(1-i) c_{D U}+(1-i)^{2} c_{D D}
$$

which corresponds to agent $i$ having belief $i$ of receiving good news at $t=1$, and having belief $i$ that, conditional on receiving bad news, assets will pay high dividends at $t=2$ (thus, with probability $(1-i)^{2}$ the economy receives bad news twice and the asset pays the low dividend $d_{D D}=0.2$.).

Agents have endowments at all non-terminal nodes. In particular, we take $\left(e_{c_{s}}, e_{Y_{s}}\right)=1$ for $s=0, U, D$. All assets, whether endowed at $t=0$ or $t=1$ pay identical dividends in $t=2$ (i.e., the endowments of assets at time 1 are of a separate vintage of assets).

\footnotetext{
${ }^{30}$ Fostel and Geanakoplos (2012a) study extensively this type of stochastic structure. They show that if agents were given the possibility to choose to invest in projects that have associated more volatility after bad news or more volatility after good news, they would always chose the former.
} 
At $t=0$ and $t=1$ agents can trade one-period financial contracts collateralized by $Y .{ }^{31}$ For each $j \in J$, the contract is denoted by the pair $\left(A_{j}, C_{j}\right) \in R_{+}^{L / L_{0}} \times R_{+}^{L / L_{T}}$. For each state $s \in S /\{0\}, A_{s j} \in R_{+}^{L_{s}}$ specifies the promises that are due, backed by the collateral $C_{s^{*} j} \in R_{+}^{L_{s^{*}}}$ deposited in state $s^{*}$.

Finally, budget sets and collateral equilibrium are analogous to the static model and are presented in detail in Appendix B.

As we did in Section 4, in what follows we consider a model with two countries that are identical in all respects except for the sets $J$ and $J^{*} .{ }^{32}$ We first characterize the autarkic equilibrium in Foreign and Home to demonstrate how leverage and tranching affect dynamics, and then we consider the equilibrium with financial integration. For expositional ease, all equations for this section are provided in Appendix C.

\subsection{Foreign Autarky: Leverage Cycle}

At each non-terminal node, agents can trade one-period debt contracts backed by $Y^{*}$. Since at $U$ all uncertainty is resolved, there is no trade; hence we only need to focus on $s=0, D$. When agents can leverage, the dynamic equilibrium is essentially different from the static equilibrium, though the equilibrium regimes in each state resemble the equilibrium regime in the static economy of Section 4. As before, in equilibrium the only contracts traded each period are the maxmin contracts: $j_{0}^{*}=p_{D}^{*}$ at $s=0$ and $j_{D}^{*}=d_{D D}$ at $s=D$. These contracts have prices $\pi_{0}^{*}=p_{D}^{*}$ and $\pi_{D}^{*}=d_{D D}$ respectively.

As shown in Figure 9, at $s=0$ there is a marginal buyer $i_{0}^{*}$ such that all investors with $i>i_{0}^{*}$ buy $Y^{*}$ with leverage. Crucially, in state $D$ all investors that bought the asset with leverage lose their initial investments (the debt they owe is the value of their entire asset holdings) and their only wealth comes from the new endowments. This means that the

\footnotetext{
${ }^{31}$ Contracts become a little more complicated with multiple periods. Multi-period contracts can destroy the anonymity of delivery, since different sellers of the contract may disagree about whether to default at intermediate states. To keep things simple and maintain anonymity, we restrict our attention to one-period contracts, for which there can be no disagreement about how much to deliver (under our hypothesis of no-recourse collateral).

${ }^{32}$ Appendix E considers extensions regarding the nature of uncertainty with partial correlation when (as a simplification) the Foreign asset cannot be leveraged. Our analysis shows that partial correlation reinforces the effects of collateral present in the model with perfect correlation.
} 


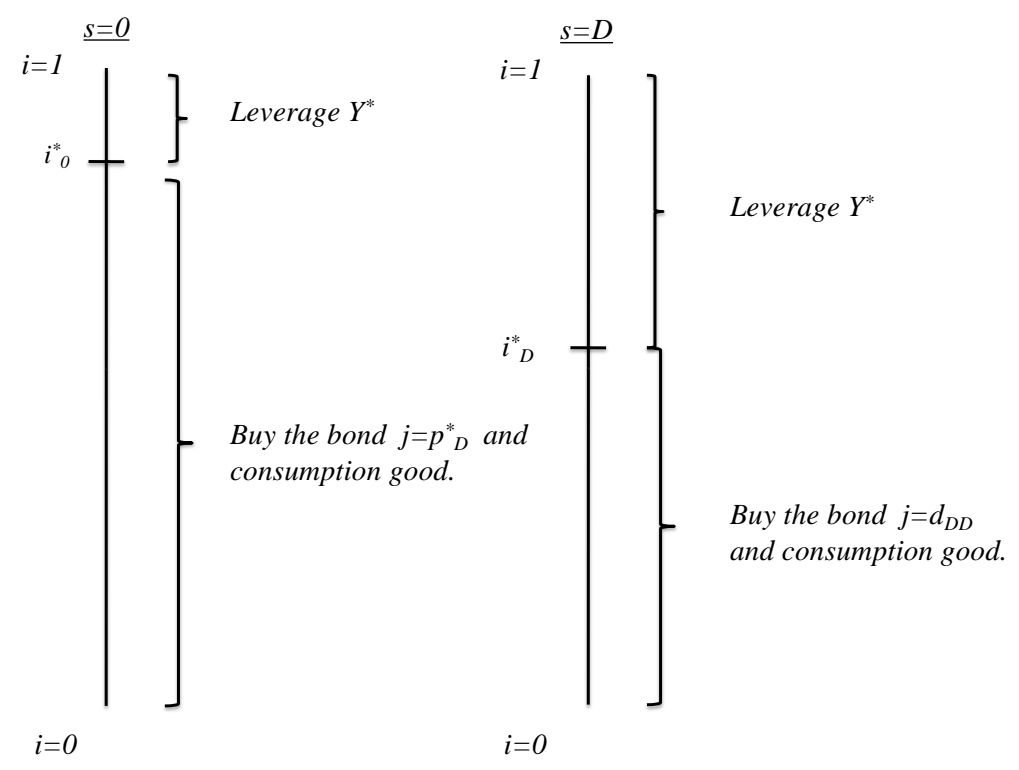

Figure 9: Dynamic equilibrium regime in Foreign.

asset must be bought by more pessimistic investors $i \in\left[0, i_{0}^{*}\right]$. In state $D$ there is a marginal buyer $i_{D}^{*}$, such that all remaining investors with $i>i_{D}^{*}$ buy $Y^{*}$ with leverage by borrowing $d_{D D}$ against each unit of the asset. For parameters above, the equilibrium is given by: $p_{0}^{*}=0.957, p_{D}^{*}=0.722, i_{0}^{*}=0.88, i_{D}^{*}=0.65$.

The price crashes by $24.55 \%$. The economy exhibits what Geanakoplos (2003) called the "Leverage Cycle:" leverage is pro-cyclical and creates excess volatility above fundamentals. Specifically, after bad news in $s=D$ the asset price falls for three reasons. First, fundamentals are worse (a bad payoff is more likely). The marginal buyer $i_{0}^{*}$ thinks the expected payoff of $Y^{*}$ is 98.5 at 0 and only 90 at $D$, a drop of $9 \%$. Second, the equilibrium margin increases in state $D$, and so investors use less leverage and the marginal buyer is therefore less optimistic. Third, investors who used leverage in the first period have less wealth after bad news as a result of the margin call to repay their debts. These optimistic buyers - the most optimistic buyers - after repaying their debt have no wealth besides their new endowments, and as a result less optimistic investors are required to buy the asset. The change in the marginal buyer from 0.88 to 0.65 , together with the change in margins, almost triples the price drop (24\%), since the change from fundamentals alone 
accounts for $9 \%$. Leverage creates excess volatility. ${ }^{33}$

\subsection{Home Autarky: Securitization Cycle}

At each non-terminal node agents can also trade one-period tranche contracts backed by $Y$.

In the dynamic economy with tranching, the equilibrium regimes in each state resemble the equilibrium regime in the static economy of Section 4. However, the dynamic equilibrium is essentially different from the static equilibrium due to wealth effects and changes in collateral values. As in the static model, without loss of generality, we can restrict our attention to a single tranche traded each period: at $s=0$ agents can trade a tranche promising $\left(0, p_{D}\right)$ at $t=1$, and at $s=D$ agents can trade a tranche promising $\left(0, d_{D D}\right)$ at $t=2$.

In equilibrium there are two marginal buyers in each state. In $s=0$, investors $i>i_{0}^{1}$ buy the risky asset and issue a down tranche promising $p_{D}$ at $t=1$, investors with $i \in\left[i_{0}^{2}, i_{0}^{1}\right]$ hold all the consumption good, and investors with $i<i_{0}^{2}$ buy the down tranche, which has a price $\pi_{0}^{T}$. In $s=D$, investors $i>i_{0}^{1}$ lose all their initial wealth after repaying their debt from issuing tranches, and they use their new wealth to purchase $Y$. There is a marginal buyer $i_{D}^{1}$ such that the new endowments of $Y$ are bought by the investors $i>i_{D}^{1}$, and the investors $i \in\left[i_{D}^{2}, i_{0}^{1}\right]$ buy all the old $Y$. All investors buying $Y$ issue a down tranche promising $d_{D D}$ at $t=2$ (note that $d_{D D}<p_{D}$ and so the value of tranche issuance falls). There is a marginal buyer $i_{D}^{2}$ such that all investors $i<i_{D}^{2}$ buy the down tranche, at a price of $\pi_{D}^{T}$. The remaining moderate investors hold the consumption good. For the same parameter values in equilibrium we get $p_{0}=1.131, p_{D}=0.844, i_{0}^{1}=0.88, i_{D}^{1}=0.65$, $\pi_{0}^{T}=0.508, \pi_{D}^{T}=0.184, i_{0}^{2}=0.24, i_{D}^{2}=0.08$. The asset price with tranching starts out significantly higher (1.131 compared to 0.957 in Foreign), due to its higher collateral value

\footnotetext{
${ }^{33}$ Compared to the original Geanakoplos (2003) model, the difference between the crashes with and without leverage are smaller in our example because of the interim endowments (the original model only has endowments at $t=0$.) As a result, the wealth effect following bad news is smaller in our model. See also Fostel and Geanakoplos (2014) for an equivalent model with two agents with heterogeneous risk-aversion and endowments. In that model, the marginal buyer is the same but the wealth of the marginal buyer decreases in the bad state, increasing the marginal utility of consumption and causing the investor to discount future payments by more.
} 


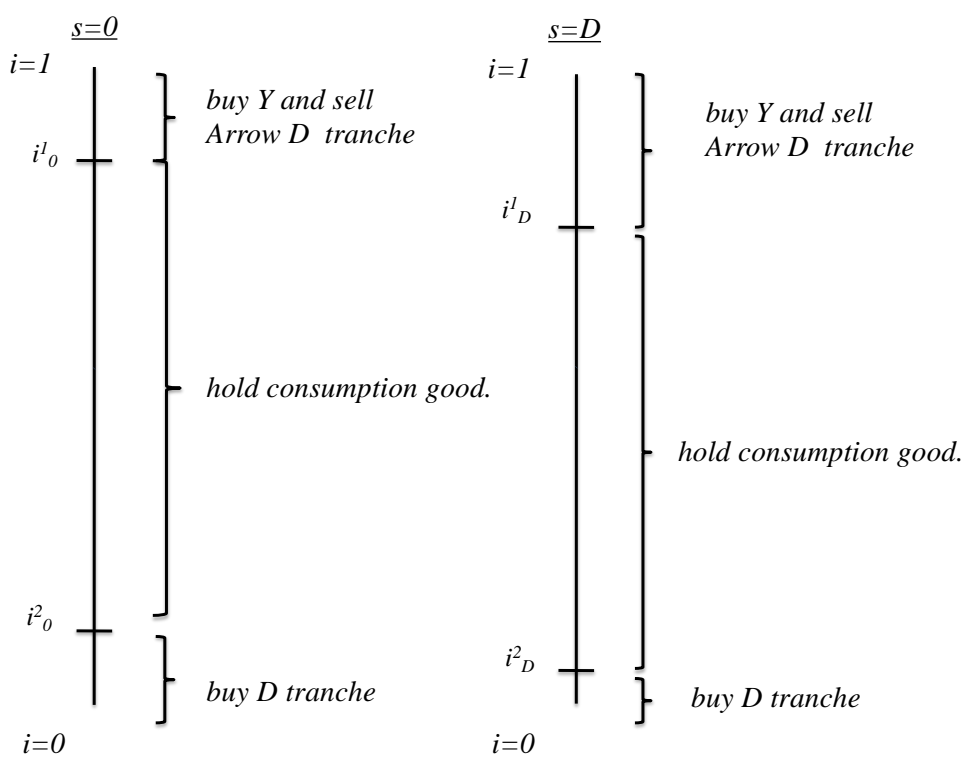

Figure 10: Dynamic equilibrium regime in Home.

(notice a bubble emerges, as was also the case in the static model with tranching).

The price crash is now $41 \%$, much larger than in the leverage economy. The model with Home tranching exhibits a "Securitization Cycle." Because tranching greatly increases the initial collateral value of the asset, which decreases following bad news, tranching creates excess volatility even compared to when the asset could be used to issue debt.

\subsection{Financial Integration in the Dynamic Model}

With financial integration, Home and Foreign agents have access to the same set of financial instruments in every non-terminal state. In equilibrium in period 0 there are two marginal buyers: $\hat{i}_{0}^{1}$, and $\hat{i}_{0}^{2}$, in both countries. The most optimistic investors, with $i \geq \hat{i}_{0}^{1}$, buy assets and use them as collateral to finance their purchases: they buy the Home asset $Y$, selling the down tranche at price $\hat{\pi}_{0}^{T}$ due at $t=1$ (which pays $\hat{p}_{D}$ in $s=D$ ); and buy $Y^{*}$ selling debt due at $t=1$ (promising $\hat{p}_{D}^{*}$ ). Optimistic agents are effectively buying the Arrow $U$ and $U^{*}$ securities. Moderate agents with $i \in\left[\hat{i}_{0}^{2}, \hat{i}_{0}^{1}\right]$ hold the consumption goods and risk-free debt backed by $Y^{*}$. The most pessimistic agents, with $i<\hat{i}_{0}^{2}$, buy down tranches. 
After bad news, important wealth distributions take place: the optimists holding $Y$ and $Y^{*}$ have limited wealth after debt repayment/margin calls, and the pessimists holding tranches have increased wealth. In $D$ there are two marginal buyers, $\hat{i}_{D}^{1}$, and $\hat{i}_{D}^{2}$ in both countries. The original investors in assets use their new endowments to purchase assets, but they have no other wealth to use after selling their initial asset holdings in order to repay their financial obligations due at $t=1$. The assets sold are purchased by new, but less optimistic, buyers with $i \in\left[\hat{i}_{D}^{1}, \hat{i}_{0}^{1}\right)$, which are the most optimistic investors who held a risk free position 0 . The most pessimistic investors, with $i<\hat{i}_{D}^{2}$, buy down tranches.

\subsubsection{Financial Integration and Asset Prices}

Table 2 presents asset prices and crashes both in autarky and with financial integration. Consistent with the static analysis, financial integration affects asset prices at $s=0$ : the Home price increases from 1.131 to 1.396 (a substantial bubble), the Foreign price decreases from 0.957 to 0.913 , and the tranche price increases from 0.508 to 0.668 .

Table 2: Prices and crashes with financial integration.

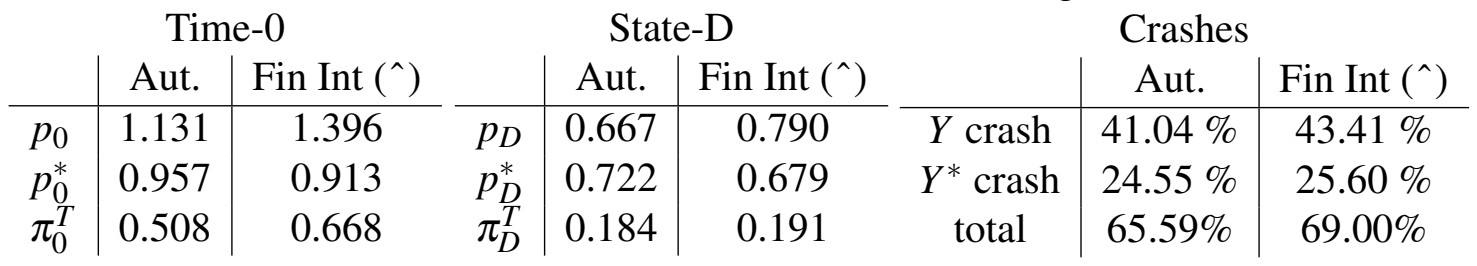

Moreover, financial integration increases the price crashes for both Home and Foreign: the Home price crash increases from $41.04 \%$ to $43.41 \%$, and the Foreign crash increases from $24.55 \%$ to $25.60 \%$. The "Securitization Cycle" mechanisms amplifying volatility in the Home autarkic equilibrium affect both Home and Foreign asset prices with financial integration. First, because the Foreign asset is priced relative to the Home asset price, the excess volatility of the Home asset transfers to the Foreign asset. Second, financial integration also amplifies volatility at Home because financial integration has increased the value of tranching, which increases the collateral value of the Home asset and therefore increases the price volatility of the Home asset. ${ }^{34}$ Because the Foreign asset is priced

\footnotetext{
${ }^{34}$ Gong and Phelan (2016b) derive a similar result in a closed-economy setting by studying how equilib-
} 
relative to the Home asset, the Foreign asset is much more volatile as well. Thus, even though in the static model the Foreign asset price decreases with financial integration, which might suggest that the economy is more stable, the Foreign price following bad news is even lower with financial integration compared to autarky because of the additional amplifying mechanisms absorbed through financial integration. This is because the large price crash in the volatile Home asset also affects the price crash in the Foreign assets, which is priced relative to the Home asset.

\subsubsection{Financial Integration, Gross Flows and the Current Account}

Gross and net flows decrease following bad news. Table 3 shows flows in $Y, Y^{*}$, and consumption goods at $s=0$ and following bad news at $s=D$. The value of Foreign purchases of Home assets decreases by $36.8 \%$ and the value of Home purchases of Foreign assets decreases by $32.5 \%$, and net flows in consumption good decrease by over $56 \%$. These results are consistent with intuition from the comparative statics varying the down payoff. In the initial period, the subsequent down payoffs next period in $t=1$ (prices of 0.79 and 0.679 ) are not nearly as severe as the possible down payoffs in $t=2$ having received bad news at $t=1\left(d_{D D}=0.2\right)$. Accordingly, the debt capacity of the Home asset dramatically decreases after bad news: the tranche price decreases from 0.668 at $s=0$ to 0.191 at $s=D$, implying investors can borrow less than one-third as much. Thus, as the possible down payoff next period decreases from $t=0$ to $t=1$, flows decrease, which is consistent with the comparative static of varying $d_{D}$.

Table 3: Dynamic global flows with financial integration.

\begin{tabular}{l|c|c|c} 
& $s=0$ & $s=D$ & Decrease (\%) \\
\hline Foreign purchases of $Y$ & 0.62 & 0.39 & $36.81 \%$ \\
Home purchases of $Y^{*}$ & 0.51 & 0.34 & $32.52 \%$ \\
Home purchases of $c^{*}$ & 0.11 & 0.05 & $56.27 \%$
\end{tabular}

rium changes when debt contracts can be used as collateral to make financial promises ("debt collateralization"). They show that debt collateralization increases the collateral value of the risky asset and increases the volatility of asset prices. 

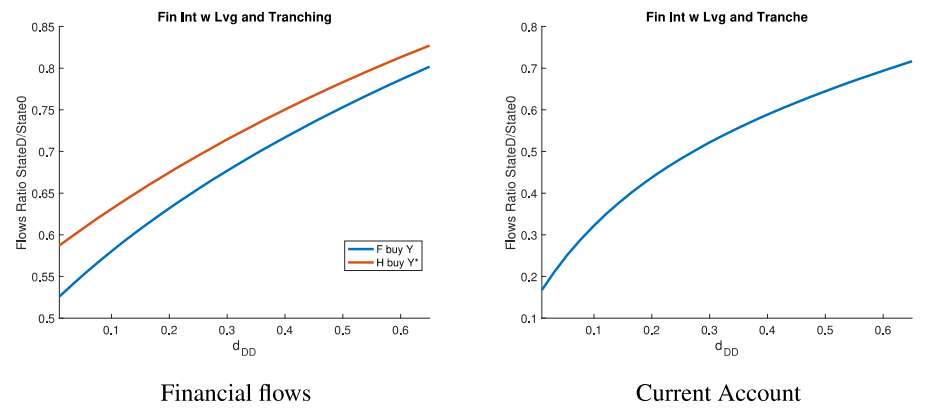

Figure 11: Ratio of flows following bad news and low tail risk.

\subsubsection{Comparative Dynamics and Low Tail Risk}

Our results are robust to varying the degree of downside risk. We provide comparative dynamics by varying the down payoff $d_{D D}$ and consider the price crashes and collapse in flows. First, the collapse in flows is greatest when downside risk is larger (lower $\left.d_{D D}\right)$. Figure 11 plots the ratio of flows at $s=D$ to the value at $s=0$. Flows collapse dramatically after bad news, with greater collapse the greater the severity (lower $d_{D D}$ ).

Second, price crashes are always bigger with financial integration regardless of the crash risk. Figure 12 plots Home and Foreign price crashes in autarky and with financial integration. Crashes in both countries are always larger with financial integration. Furthermore, our results continue to hold when news about the Home and Foreign assets are only partially correlated, which would provide diversification motives for trade. Indeed, the results in Appendix E show that diversification mechanisms reinforce collateral-based mechanisms rather than undoing them. Collateral-driven trades continue to amplify volatility, and the effects with partial correlation can be even larger.

\section{Conclusion}

We presented a two-country general equilibrium model with collateralized lending and tranching in which global capital flows are driven by different abilities to use assets as collateral across countries. All countries have access to the same financial instruments after financial integration, yet price-convergence does not occur due to gap in collateral 


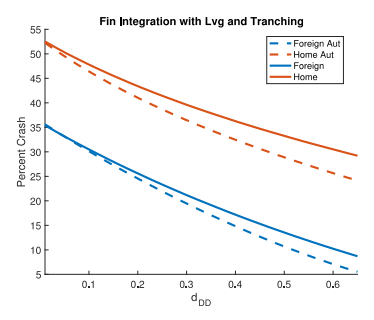

Figure 12: Price crashes in autarky and with Financial integration. Sensitivity of price volatility to low tail risk.

values. Financial integration provides Foreign access to attractive Home financial assets, and cross-border flows arise in both directions as a result of general equilibrium changes in the prices of currently available assets. These flows arise as a way for countries to share scarce collateral and to trade contingent claims, including safe and negative beta assets. Differences in the ability to use collateral are enough to generate global financial flows. Moreover, Home always run a current account deficit, proportional to the positive collateral gap.

Our results imply that collateral-driven flows increase asset price volatility globally and lead to collapses in flows following bad news about fundamentals. Financial integration leads to portfolio rebalancing and cross-country asset purchases, especially among investors with the highest demand for leverage. The resulting flows have important consequences for financial stability, exporting volatility abroad and amplifying volatility globally. Thus, our results can explain flows among similarly-developed countries that increase volatility rather than dampen shocks. 


\section{References}

Acharya, Viral V, and Philipp Schnabl. 2010. "Do global banks spread global imbalances? Asset-backed commercial paper during the financial crisis of 2007-09." IMF Economic Review, 58(1): 37-73. 1

Andritzky, Jochen R. 2012. Government bonds and their investors: What are the facts and do they matter? International Monetary Fund. 1, 1

Angeletos, George-Marios, and Vasia Panousi. 2011. "Financial Integration, Entrepreneurial Risk and Global Dynamics." Journal of Economic Theory, 146(3): 863896. 2

Baklanova, Viktoria, Cecilia Caglio, Macro Cipriani, and Adam Copeland. 2017. "The Use of Collateral in Bilateral Repurchase and Securities Lending Agreements." Federal Reserve Bank of New York Staff Report 758. 1

Bekaert, Geert, and Campbell R Harvey. 2000. "Foreign speculators and emerging equity markets." The Journal of Finance, 55(2): 565-613. 6

Bertaut, Carol, Laurie Pounder DeMarco, Steven Kamin, and Ralph Tryon. 2012. "ABS inflows to the United States and the global financial crisis." Journal of International Economics, 88(2): 219-234. 1, 13

Bruno, Valentina, and Hyun Song Shin. 2014. "Cross-border banking and global liquidity." The Review of Economic Studies, rdu042. 1

Caballero, Ricardo J, and Alp Simsek. 2016. "A Model of Fickle Capital Flows and Retrenchment: Global Liquidity Creation and Reach for Safety and Yield." National Bureau of Economic Research. 2

Caballero, Ricardo J., Emmanuel Farhi, and Pierre-Olivier Gourinchas. 2008. "An Equilibrium Model of "Global Imbalances" and Low Interest Rates." American Economic Review, 98(1): 358-93. 2

Copeland, Adam, Antoine Martin, and Michael Walker. 2014. "Repo Runs: Evidence from the Tri-Party Repo Market.” The Journal of Finance, 69(6): 2343-2380. 1

Davis, J Scott. 2014. "Financial integration and international business cycle comovement." Journal of Monetary Economics, 64: 99-111. 1

Devereux, Michael B, and James Yetman. 2010. "Leverage constraints and the international transmission of shocks." Journal of Money, Credit and Banking, 42(s1): 71-105. 2

Forbes, Kristin J, and Francis E Warnock. 2012. "Capital flow waves: Surges, stops, flight, and retrenchment." Journal of International Economics, 88(2): 235-251. 2 
Fostel, A., and J. Geanakoplos. 2008. "Leverage Cycles and The Anxious Economy." American Economic Review, 98(4): 1211-1244. 2

Fostel, Ana, and John Geanakoplos. 2012a. "Tranching, CDS, and Asset prices: How Financial Innovation Can Cause Bubbles and Crashes." American Economic Journal: Macroeconomics, 4(1): 190-225. 2

Fostel, Ana, and John Geanakoplos. 2012b. "Why Does Bad News Increase Volatility And Decrease Leverage?" Journal of Economic Theory, 147(2): 501-525. 2, 4.1

Fostel, Ana, and John Geanakoplos. 2014. "Endogenous collateral constraints and the leverage cycle.” Annu. Rev. Econ., 6(1): 771-799. 33

Fostel, Ana, and John Geanakoplos. 2015. "Leverage and default in binomial economies: a complete characterization.” Econometrica, 83(6): 2191-2229. 2, 14

Fostel, Ana, and John Geanakoplos. 2016. "Financial Innovation, Collateral, and Investment." American Economic Journal: Macroeconomics, 8(1): 242-284. 2, 14

Geanakoplos, John. 1997. "Promises Promises.” Vol. 27, 285-320, Addison-Wesley Publishing Co. 2

Geanakoplos, John. 2003. "Liquidity, Default and Crashes: Endogenous Contracts in General Equilibrium.” Vol. 2, 170-205, Econometric Society Monographs. 2, 5.2, 33

Geanakoplos, John, and William R Zame. 2014. "Collateral equilibrium, I: a basic framework." Economic Theory, 56(3): 443-492. 2, 3

Gong, Feixue, and Gregory Phelan. 2016a. "A Collateral Theory of the Cash-Synthetic Basis.” Working Paper, Williams College. 2

Gong, Feixue, and Gregory Phelan. 2016b. "Debt Collateralization, Capital Structure, and Maximal Leverage." Working Paper, Williams College. 10, 2, 34

Hale, Galina, and Maurice Obstfeld. 2016. "The Euro and the geography of international debt flows." Journal of the European Economic Association, 14(1): 115-144. 1

Imbs, Jean. 2006. "The real effects of financial integration." Journal of International Economics, 68(2): 296-324. 1

Kalemli-Ozcan, Sebnem, Elias Papaioannou, and Fabrizio Perri. 2013. "Global banks and crisis transmission.” Journal of international Economics, 89(2): 495-510. 1

Kose, M Ayhan, Christopher Otrok, and Charles H Whiteman. 2008. "Understanding the evolution of world business cycles." Journal of international Economics, 75(1): 110-130. 1 
Lane, Philip R, and Gian Maria Milesi-Ferretti. 2007. "The external wealth of nations mark II: Revised and extended estimates of foreign assets and liabilities, 1970-2004." Journal of international Economics, 73(2): 223-250. 1

Loutskina, Elena, and Philip E Strahan. 2015. "Financial integration, housing, and economic volatility." Journal of Financial Economics, 115(1): 25-41. 1

Maggiori, Matteo. 2017. "Financial intermediation, international risk sharing, and reserve currencies." American Economic Review, 107(10): pp. 3038-71. 2, 28

Maggiori, Matteo, Brent Neiman, and Jesse Schreger. 2017. "Unpacking Global Capital Flows." working paper Harvard. 11

Mendoza, Enrique G, and Vincenzo Quadrini. 2010. "Financial globalization, financial crises and contagion." Journal of monetary economics, 57(1): 24-39. 2

Mendoza, Enrique G, Vincenzo Quadrini, and Jose-Victor Rios-Rull. 2009. "Financial intergration, financial development, and global imbalances." Journal of Political Economy, 117: 3. 2

Phelan, Gregory. 2015. "Collateralized Borrowing and Increasing Risk.” Economic Theory, 1-32. 2

Phelan, Gregory, and Alexis Akira Toda. 2018. "Securitized Markets, International Capital Flows, and Global Welfare." forthcoming, Journal Financial Economics. 2

Santis, Giorgio, and Bruno Gerard. 1997. "International asset pricing and portfolio diversification with time-varying risk." The Journal of Finance, 52(5): 1881-1912. 1

Shin, Hyun Song. 2012. "Global Banking Glut and Loan Risk Premium.” IMF Economic Review, 60(2): 155-192. 1, 1, 13

Ueda, Kozo. 2012. "Banking globalization and international business cycles: Crossborder chained credit contracts and financial accelerators." Journal of international Economics, 86(1): 1-16. 2

Wang, Haobin. 2016. "Quantitative Easing, Collateral Constraints, and Financial Spillovers." Yale University Working Paper. 9

Willen, Paul. 2004. "Incomplete markets and trade.” FRB of Boston Working Paper, FRB of Boston Working Paper. 2 